iRASD Journal of Management

闵义义

iRASD

Volume 3, Number 3, 2021, Pages 200 - 207

Journal Homepage:

https://journals.internationalrasd.org/index.php/iom

\title{
Impact of Perceived Organizational Support on Organizational Commitment among University Employees: Moderating Role of Job Experience
}

Sadia Iqbal ${ }^{1}$, Saadia Zia², Dr. Umbreen Khizar ${ }^{3}$

${ }^{1}$ 1. PhD scholar, Department of Applied Psychology, The Islamia University of Bahawalpur, Pakistan Email: sadiaiqbal.ms@gmail.com

2 2. Lecturer, Department of Psychology, Institute of Southern Punjab, Multan, Pakistan, Email: ziasaadia9@gmail.com

3. Assistant Professor, Department of Psychology, Institute of Southern Punjab, Multan, Pakistan, Email: umbreenkhizar@gmail.com

\section{ARTICLE INFO}

\section{Article History:}

Received:

Revised:

Accepted:

09, 2021

November 19, 2021

November 27, 2021

Available Online: November 29, 2021

\section{Keywords:}

Perceived organizational support

Job experience

Organizational commitment

University employees

\begin{abstract}
The study was aimed to investigate the moderating role of job experience between perceived organizational support and organizational commitment among university employees. The target population was the employees of the Institute of Southern Punjab, Multan, Pakistan. The study was based on a correlational research design. 128 employees were sampled through a simple random sampling technique. Data was collected by survey method through Perceived Organizational Support Scale (POSS) by Eisenberger, Huntington, Hutchison, and Sowa (1986) and Organizational Commitment Questionnaire (Mowday, Steers, \& Porter, 1979). Demographic variable job experience was measured as moderating variables between perceived organizational support and organizational commitment. The collected data was analyzed through Statistical Package for Social Sciences (SPSS 23). Correlation, regression, and moderation analysis were used to interpret data statistically. The results revealed a significant correlation between perceived organizational support and organizational commitment. The regression analysis indicated a significant impact of perceived organizational support on organizational commitment. The findings suggest a significant role of moderators (job experience) between organizational support and organizational commitment. Further study in organizational psychology would be recommended in the development of an encouraging and supportive workplace environment for employees.
\end{abstract}

(C) 2021 The Authors, Published by iRASD. This is an Open Access article under the Creative Common Attribution Non-Commercial 4.0

Corresponding Author's Email: ziasaadia9@gmail.com

\section{Introduction}

Working environment is changing rapidly in business, filled with uncertainty as the companies are frequently merging and acquisitions, this phenomenon causes trust issues between employee and employers. It is required to comprehend the importance of positive relation between organizations and employees to enhance organizational loyalty, reducing absentees, increasing performance and organizational commitment. As organizational context are continuously changing becoming more challenging, dynamic and competitive. It requires higher level of organizational commitment. In these circumstances if organizations demonstrate greater assurance and commitment toward their employees, then employees reciprocate greater commitment and engagement to organizational goals and purpose (Rhoades, Eisenberger, \& Armeli, 2001). 
Researchers reported organizational support as a potential determinant of organizational commitment, contributing to enhance organizational loyalty, better job performance and reciprocates higher engagement in organizational behavior ( $\mathrm{Li}, 2018$ ). Role of perceived organizational support (POS) was found to have positive and significant relation with organizational commitment and professional satisfaction (Akram, Siddiqui, Nawaz, Ghauri, \& Cheema, 2011; Aube, Rousseau, \& Morin, 2007). Therefore, perception of organizational support is assess on regular basis to ensure positive outcomes for both profitability and organizational progress (Krishnan \& Mary, 2012).

Organizational commitment is defined as a view of an employee to their organization. Organizational commitment is the nature of employee's connection to their workplace (Nawaz et al., 2021; Shahnawaz \& Jafri, 2009) and their involvement with the organization (Mowday, Steers, \& Porter, 1979). Organizational commitment is a very significant aspect of organizational environment and has direct effects on the organizational workings. Due to this, employees with high organizational commitment can recognize organizational goals better and demonstrate clear motives in achieving organizational goals (Nguyen \& Tu, 2020). Organizational committed employee have more enthusiasm and put an extra effort to achieve the organizational goals. In addition, if human resources are the greatest assets of an organization then organizational commitment should be seen as the organizational greatest competitive advantage (Nehmeh, 2009).

It has been found through empirical researches that POS has positive effects on organizational commitment, professional commitment (Tang \& Hu, 2017), affective commitment (Lee \& Peccei, 2011), job satisfaction and willingness to stay at an organization (Kurtessis et al., 2017; Nawaz, Afzal, \& Shehzadi, 2013). Relationship between employees and organization is best explained by perceive organizational support as a social exchanging process including material and non-material exchange processes. Perceived organizational support relates to the way an organization treats its employees. It is influenced by overall organizational treatment to employees, therefore affecting employee's interpretation of organization motives. Organizations willingness to pay good and reasonable salaries, possible responses toward employees' future, illness, error, and highperformance influence employees' motivation level and work. Perceive organizational support enhances employees' performance, attitudes, and actions to organizational goals (Sun, 2017).

In recent times, with the advancements in businesses and global development, the rise of competition on the global scale makes the organizations increase their demands from their employees. On the flip side, with advancements in technology and social developments, the needs and wishes of the employees have also grown. This has led to a dynamic in the businesses to look after their employees as their greatest assets (Rousseau \& Aubé, 2014).

Previous studies concerning organizational culture for example found if values, beliefs, and behavioral patterns remain constant, it is then considered as a corporate culture. (Mathew \& Panchanatham, 2010) explored that in the organizational working environment, things are done according to the organizational culture. Furthermore, it is a process of human association towards their communities to develop their environmental settings (Allaire \& Firsirotu, 1984). So far, the literature has thus mainly considered POS as a positive element in the workplace, having beneficial effects for both employees and organizations (Eisenberger \& Stinglhamber, 2011).

Two significant phenomena are indicated by perceived organizational support. Firstly, organizational support is crucial for employees as employee use their energies and time to meet the job and to complete their work, required extra efforts to attain work goals. Therefore, employee needs organizational support backup that benefited both employers and employees. Secondly, employees perceive organizational positive treatment as incentive or prize and works for mutual goals and interests in an efficient manner (Schaufeli \& Bakker, 2013). 


\section{Literature Review}

An organization's enactment is directly related to its worker's performance. One of the biggest determinant of worker's performance is the amount of time they have spent with the organization (as longer affiliations with an organization provides greater experience regarding their work in the organization and thus experience brews better performance (McDaniel, Schmidt, \& Hunter, 1988). Attraction-Selection-Attrition (ASA) model, suggest that employees having greater affiliation and loyalties to their organization align themselves with organizational values and goals thus developing a stronger workforce for the organization (ASA model) (Schneider, 1987).this affiliation will help the employee to leads to have greater job experience. As they become more accustomed and inclined towards the organizational goals (Kristof-Brown, Zimmerman, \& Johnson, 2005).

Moreover, job experience brings innovative human resources distinction experienced employees to new ones (Quińones, Ford, \& Teachout, 1995). Job experience may prove beneficial in increasing not only employee's human capital (greater experience leads to greater familiarity with job which leads to expertise in the job-related task) but also organizational human capital (greater familiarity with the organization's workings, norms, culture, staff management, history and goals). Such human capital in the organization assists the employees to better perform their duties, to avoid mishaps and issues in the organization. Above all better familiarity with the workforce helps them to distinguish noticeable workers as they know how to work efficiently from employees more assistance and guidance with their work- (Humphrey, Morgeson, \& Mannor, 2009). A study was carried to investigate the multiple entities of job experience show positive incremental effects on job commitment (Shair et al., 2021).

Organizations are rapidly changing as the work place becomes increasingly competitive, demanding more from the employees, compelling the organizations to show greater commitment towards their employees which resonates with the employees as they show greater commitment with the organization and thus show better performance (Chien, Hsu, Zhang, Vu, \& Nawaz, 2021; Kurtessis et al., 2017).

An important factor determining the organizational commitment besides organizational support is their job experience. Employee's job experience refers as the years / time of services they have attained at their respective organizations. As the employee's job experience increases their performance level also increase (McDaniel et al., 1988). This could be because longer tenured workers have better acquainted with their jobs and have comparatively higher professional achievements, therefore their performance level increases ( $\mathrm{Ng} \&$ Sorensen, 2008; Ullah, Kamran, Akram, Nawaz, \& Rehman, 2021). Ng and Feldman (2010) stated positive relation between job experience and job performance but to a certain level then it starts to weaken the relation. According to Bartlomiejczuk (2015) organizational commitment show more significant results between 3-6 years, than show decrease in commitment until about 14 years. It might be due to the reason there is less motivation to achieve career advancement as job experience increases ( $\mathrm{Ng} \&$ Feldman, 2010).

The main perspective of job experience is that long term employees (greater experience) have greater authority, more knowledgeable about policies and values (Schmidt \& Posner, 1983). Similarly they engage less in searching job alternatives (Rhoades et al., 2001). While in another study it was stated that short term employees (less job experience) are more positive passionate, displaying more organizational commitment (Agarwal \& Bhargava, 2013). A study was carried in Karachi, Pakistan showing positive moderating effect of tenure (job experience) on organizational commitment (Usmani, Kumari, \& Siddiqui, 2016).

For any organizational management dealing/supervising employees is an integral part. Organizational productivity and quality is determined by employee's behavior to organizational values and goals. By enhancing satisfaction and commitment among employees, organizations tried to have more effective men power, reduces the chances of absentees and turnover. If organizations support their employees they will choose to stay in the organization for a long period of time. Researches shows job experience is positively associated with commitment and older employees prefer to stay in their organization and 
have higher level of organizational commitment. Probably they have limited alternative of jobs offers or maybe they found it convenient to stay in the organization. Whatever the reason is, organizational commitment is the best strategy to keep the employees in hands. The aim of current study is to assess effect of job experience in the relationship between perceived organizational support and organizational commitment. There are numerous studies that focus on experience and commitment in separately, but a few are there on linking perceived organizational support, job experience and organizational commitment.

\section{Material and Method}

This is a quantitative study based on correlational study design with survey method. The sample consists of employees from an educational organization, Institute of Southern Punjab, Multan, Pakistan. Sample size was 128 employees (male and female) determined through G-Power software and simple random sampling technique of probability sampling was used for the purpose of data collection. Data was gathered from institutional employees at institutional setting. Job experience used to assess interaction effect between perceived organizational support and organizational commitment.

\subsection{Instruments}

The three-research instrument were used to measure the study variable. Perceived Organizational Support Scale (POSS) consists of 36- items, in seven. Likert scale and based on survey method. Some items have reversed scoring. Higher scores indicate higher perception of organizational support (Eisenberger, Huntington, Hutchison, \& Sowa, 1986). Organizational Commitment Questionnaire (OCQ) used to measure employees' organizational commitment (Mowday et al., 1979). It obtains responses on 7-point Likert scale and consists of 15 items. Several items were negatively phrased and reverse scored to reduce response bias. Higher score indicates higher levels of organizational commitment.

\subsection{Procedure}

Employees of Institute of Southern Punjab were approached and informed consent was provided to each respondent. It was ensured that quality of confidentiality will be maintained. SPSS-23 was used to analyze data with the significance level of 0.05 . With the help of descriptive and inferential statistics, results were concluded. Regression analysis was used to measure the moderating role of job experience on perceive organizational support and organizational commitment.

\section{Table 1}

Experience of the respondents

\begin{tabular}{cccc}
\hline Experience & Frequency & Percent & Cumulative Percent \\
\hline $1-5$ years & 83 & 64.8 & 64.8 \\
$5-10$ year & 35 & 27.3 & 92.2 \\
More than 10 years & 10 & 7.8 & 100.0 \\
Total & 128 & 100.0 & \\
\hline
\end{tabular}

Data analysis shows percentage of respondent's job experience. $65 \%$ respondents have 1-5 years of job experience, $27 \%$ employees have 5-10 years and $10 \%$ employees have more than 10 years of job experience.

Table 2

Mean, Standard Deviation and Correlation Matrix

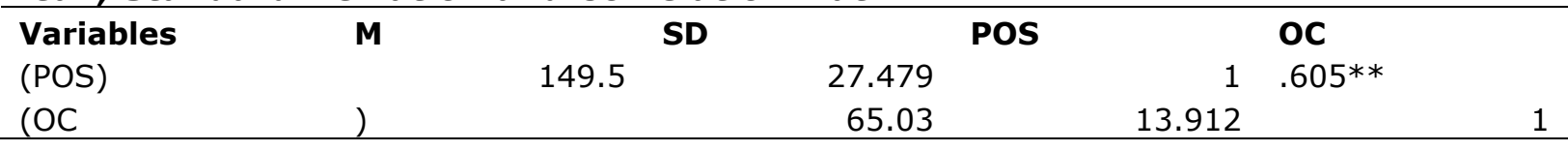

Table 2 shows the significant positive correlation among perceive organizational support, and organizational commitment. ${ }^{*} p \leq .05$. $* *, p=.001$. 
Figure 1: Experience of the respondents

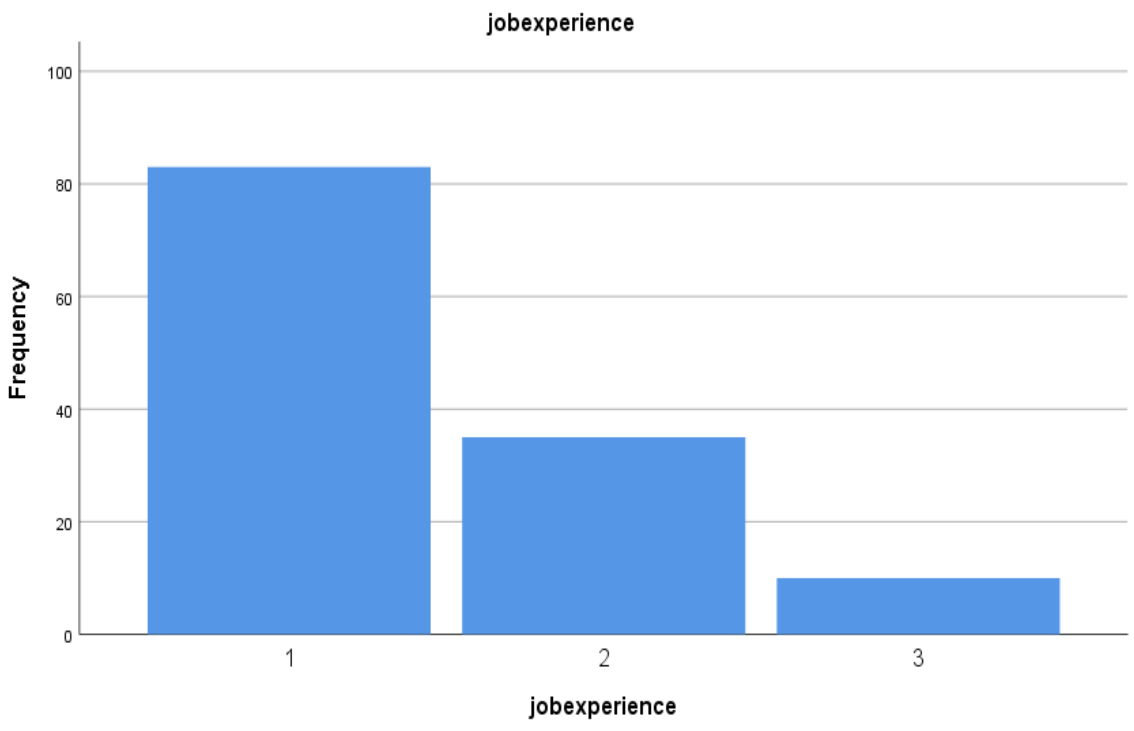

Table 3

Standard Regression Model showing the impact of Organizational Support on organizational Commitment

\begin{tabular}{lccccc}
\hline Predictor & $B$ & Std.Error & Beta & $t$-test & $P$-value \\
\hline Constant) & 21.603 & 5.182 & & 4.169 & $.000^{* * *}$ \\
Organizational & .292 & .034 & .605 & 8.534 & $.000 * * *$ \\
Commitment & & & & &
\end{tabular}

Table 3 shows the significant impact of perceive organizational support on organizational commitment $(\mathrm{R} 2=.366$, Adjusted R2 $=.361,(F=72.822, \mathrm{p}<=0.05)$.

Table 4

Regression Result

\begin{tabular}{|c|c|c|c|c|}
\hline Variables & Coeff. & SE & $\mathbf{t}$ & prob. \\
\hline Constant & 53.288 & 12.552 & 4.245 & 0.000 \\
\hline POS $(X)$ & 0.078 & 0.084 & 0.929 & 0.354 \\
\hline JE (M) & -23.548 & 8.460 & -2.784 & 0.006 \\
\hline POS $\times$ JE & 0.162 & 0.058 & 2.776 & 0.006 \\
\hline Low POS & 0.240 & 0.039 & 6.205 & 0.000 \\
\hline Moderate POS & 0.313 & 0.035 & 8.981 & 0.000 \\
\hline High POS & 0.428 & 0.060 & 7.153 & 0.000 \\
\hline \multicolumn{5}{|c|}{ Model Diagnostics } \\
\hline R2 & & & & 0.404 \\
\hline$\Delta R 2$ & & & & 0.037 \\
\hline$\Delta \mathrm{F}$ & & & & 7.706 \\
\hline MSE & & & & 118.198 \\
\hline
\end{tabular}

Regression model shows significant direct effect of moderating variable (job experience) on relationship between perceived organizational support and organizational commitment $(p<0.05)$.

\section{Discussion}

The current study aims to investigate the moderating role of job experience between perceived organizational support and organizational commitment among university employees. Table 1 shows the experience of employees, pointing largest frequency $64.3 \%$ employees have 1-5 years' job experience, followed by $27.3 \%$ have 5-10 years job experience and $7.3 \%$ having more than 10 years job experience. Table 2 shows positively significant correlation between perceived organizational support and organizational commitment. Result from tables 3 shows that perceives organizational support significantly determine $(36.6 \%)$ organizational commitment among employees. 
Significant direct effect of moderating variable (job experience) on perceived organizational support and organizational commitment shown in table 4, the interaction effect is significant $(\beta=.1617,[.0464, .2770], P<0.05)$.

Therefore, it is determined that there is moderating effect of job experience between perceived organizational support and organizational commitment. From the above table, the change in $\Delta \mathrm{R}^{2}$ for Interaction term (perceived organizational support and job experience) is .0371 , means that variability percentage of organizational commitment increased by $37.1 \%$ with the addition of job experience in perceived organizational support. Moreover, conditional effect of perceived organizational support at different value of job experience (moderator) were analyzed, highlighting highly significant outcomes $(p<0.05)$. Similarly in Fig 1, job experience was founded to influence the relationship between perceived organizational support and organizational commitment in a positive direction. The central point of view on job experience is that long-term employees (have more power and are more knowledgeable about principles and organizational or might be because longertenured employees are more familiar with their tasks and have comparably higher professional accomplishments, therefore their performance level rises ( $\mathrm{Ng} \&$ Sorensen, 2008; Schmidt \& Posner, 1983).

\section{Figure 2: Interaction effect of moderating variable (job experience) on relationship between perceived organizational support and organizational commitment}

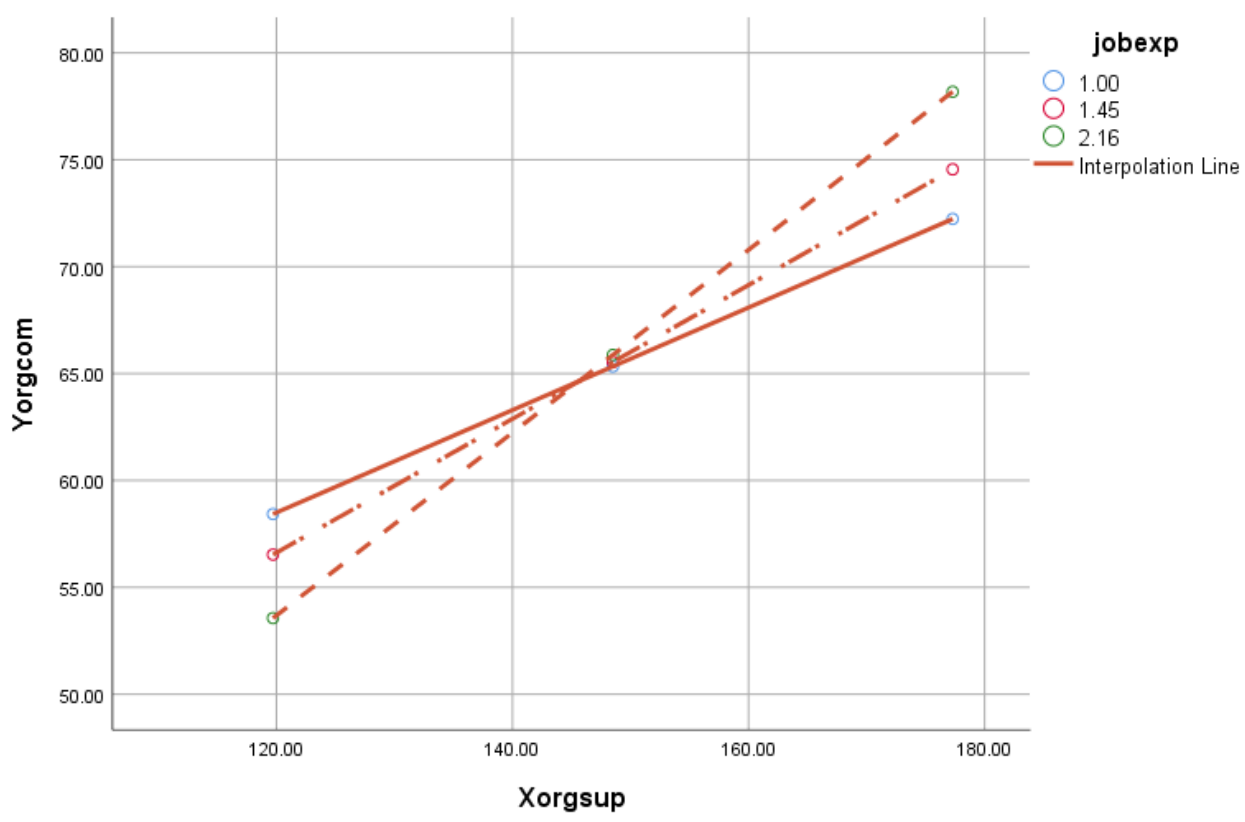

\section{Policy Recommendations}

The study investigated the moderating role of job experience among perceived organizational support and organizational commitment among university employees. The study covered the sample of the 128 employees of the Institute of Southern Punjab, Multan, Pakistan by simple random sampling and questionnaire followed Perceived Organizational Support Scale (POSS) by Eisenberger, Huntington, Hutchison, and Sowa (1986) and Organizational Commitment (Mowday, Steers, \& Porter, 1979). According to correlation, regression and moderation analysis, examined significant effect of perceived organizational support on organizational commitment. The results also suggested significant role of moderators (job experience) between organizational support and organizational commitment.

Based on study conclusions and findings, it is recommended, that organizations must consider the significance of organizational support as one of the predictors of employee's job commitment. Job experience must be catered and valued in this regard as 
well. Future researches are suggested to study these variables in more complex research designs and including variety of other variables to explore various other phenomenon in this domain for the sake of better understanding of organizational behaviors.

\section{References}

Agarwal, U. A., \& Bhargava, S. (2013). Effects of psychological contract breach on organizational outcomes: Moderating role of tenure and educational levels. Vikalpa, 38(1), 13-26. doi:https://doi.org/10.1177/0256090920130102

Akram, K., Siddiqui, S. H., Nawaz, M. A., Ghauri, T. A., \& Cheema, A. K. H. (2011). Role of knowledge management to bring innovation: an integrated approach. Cell, 92(333), 6183035.

Allaire, Y., \& Firsirotu, M. E. (1984). Theories of organizational culture. Organization studies, 5(3), 193-226. doi:https://doi.org/10.1177/017084068400500301

Aube, C., Rousseau, V., \& Morin, E. M. (2007). Perceived organizational support and organizational commitment: The moderating effect of locus of control and work autonomy. Journal of managerial Psychology, 22(5), 479-495. doi:https://doi.org/10.1108/02683940710757209

Bartlomiejczuk, G. (2015). How do Recognition Programs Impact Employee Engagement and How have Companies with a Large Global Footprint Structured such Programs to Drive Results?

Chien, F., Hsu, C.-C., Zhang, Y., Vu, H. M., \& Nawaz, M. A. (2021). Unlocking the role of energy poverty and its impacts on financial growth of household: is there any economic concern. Environmental Science and Pollution Research, 1-14. doi:https://doi.org/10.1007/s11356-021-16649-6

Eisenberger, R., Huntington, R., Hutchison, S., \& Sowa, D. (1986). Perceived organizational support. Journal of applied psychology, 71(3), 500.

Eisenberger, R., \& Stinglhamber, F. (2011). Perceived organizational support: Fostering enthusiastic and productive employees: American Psychological Association.

Humphrey, S. E., Morgeson, F. P., \& Mannor, M. J. (2009). Developing a theory of the strategic core of teams: A role composition model of team performance. Journal of applied psychology, 94(1), 48-61. doi:https://doi.org/10.1037/a0012997

Krishnan, J., \& Mary, V. S. (2012). Perceived organisational support-an overview on its antecedents and consequences. International Journal of Multidisciplinary Research, 2(4), 2-3.

Kristof-Brown, A. L., Zimmerman, R. D., \& Johnson, E. C. (2005). Consequences OF INDIVIDUALS'FIT at work: A meta-analysis OF person-job, person-organization, person-group, and person-supervisor fit. Personnel psychology, 58(2), 281-342. doi:https://doi.org/10.1111/j.1744-6570.2005.00672.x

Kurtessis, J. N., Eisenberger, R., Ford, M. T., Buffardi, L. C., Stewart, K. A., \& Adis, C. S. (2017). Perceived organizational support: A meta-analytic evaluation of organizational support theory. Journal of management, 43(6), 1854-1884. doi:https://doi.org/10.1177/0149206315575554

Lee, J., \& Peccei, R. (2011). Discriminant validity and interaction between perceived organizational support and perceptions of organizational politics: A temporal analysis. Journal of Occupational and Organizational Psychology, 84(4), 686-702. doi:https://doi.org/10.1348/096317910X511197

$\mathrm{Li}, \mathrm{D}$. Y. (2018). The impact of organizational support on job adaptation of new employees-The mediating role of self-care management. China Management Informationization, 21(7), 95-96.

Mathew, R. V., \& Panchanatham, N. (2010). An empirical analysis of the impact of various dimensions of work-life balance on organizational commitment among service sector employees in India. International Journal of Management Studies (IJMS), 17(1), 129-147.

McDaniel, M. A., Schmidt, F. L., \& Hunter, J. E. (1988). Job experience correlates of job performance. Journal of applied psychology, 73(2), 327-330. doi:https://doi.org/10.1037/0021-9010.73.2.327

Mowday, R. T., Steers, R. M., \& Porter, L. W. (1979). The measurement of organizational commitment. Journal of vocational behavior, 14(2), 224-247. doi:https://doi.org/10.1016/0001-8791(79)90072-1 
Nawaz, M. A., Afzal, N., \& Shehzadi, K. (2013). Problems of formally employed women: A case study of Bahawalnagar, Pakistan. Asian Journal of Empirical Research, 3(10), 1291-1299.

Nawaz, M. A., Hussain, M. S., Kamran, H. W., Ehsanullah, S., Maheen, R., \& Shair, F. (2021). Trilemma association of energy consumption, carbon emission, and economic growth of BRICS and OECD regions: quantile regression estimation. Environmental Science and Pollution Research, 28(13), 16014-16028. doi:https://doi.org/10.1007/s11356-020-11823-8

Nehmeh, R. (2009). What is organizational commitment, why should managers want it in their workforce and is there any cost effective way to secure it. Swiss management center, 5, 45-46.

$\mathrm{Ng}, \mathrm{T}$. W., \& Feldman, D. C. (2010). Organizational tenure and job performance. Journal of management, 36(5), 1220-1250. doi:https://doi.org/10.1177/0149206309359809

Ng, T. W., \& Sorensen, K. L. (2008). Toward a further understanding of the relationships between perceptions of support and work attitudes: A meta-analysis. Group \& Organization Management, 33(3), 243-268. doi:https://doi.org/10.1177/1059601107313307

Nguyen, T. H., \& Tu, V. B. (2020). Social Responsibility, Organizational Commitment, and Organizational Performance: Food Processing Enterprises in the Mekong River Delta. The Journal of Asian Finance, Economics and Business, 7(2), 309-316. doi:https://doi.org/10.13106/jafeb.2020.vol7.no2.309

Quińones, M. A., Ford, J. K., \& Teachout, M. S. (1995). The relationship between work experience and job performance: A conceptual and meta-analytic review. Personnel psychology, 48(4), 887-910. doi:https://doi.org/10.1111/j.17446570.1995.tb01785.x

Rhoades, L., Eisenberger, R., \& Armeli, S. (2001). Affective commitment to the organization: the contribution of perceived organizational support. Journal of applied psychology, 86(5), 825. doi:https://doi.org/10.1037/0021-9010.86.5.825

Rousseau, V., \& Aubé, C. (2014). The reward-performance relationship in work teams: The role of leader behaviors and team commitment. Group Processes \& Intergroup Relations, 17(5), 645-662. doi:https://doi.org/10.1177/1368430214529465

Schaufeli, W., \& Bakker, A. (2013). Burnout en bevlogenheid.

Schmidt, W. H., \& Posner, B. Z. (1983). Managerial values in perspective. AMA Survey Report.

Schneider, B. (1987). The people make the place. Personnel psychology, 40(3), 437-453. doi:https://doi.org/10.1111/j.1744-6570.1987.tb00609.x

Shahnawaz, M., \& Jafri, M. H. (2009). Job attitudes as predictor of employee turnover among stayers and leavers/hoppers. Journal of Management Research, 9(3), 159166.

Shair, F., Shaorong, S., Kamran, H. W., Hussain, M. S., Nawaz, M. A., \& Nguyen, V. C. (2021). Assessing the efficiency and total factor productivity growth of the banking industry: do environmental concerns matters? Environmental Science and Pollution Research, 28(16), 20822-20838. doi:https://doi.org/10.1007/s11356-020-11938-y

Sun, X. (2017). Research on relationship between perceived organizational support, psychological contract and work burnout: Taking state-owned enterprises in Shandong province as an example. (Master), Guizhou University of Finance and Economics,

Tang, J., \& Hu, N. (2017). Research on the effect of perceived organizational support on the job satisfaction of middle school teachers. Mathematics in Practice and Theory, 47(24), 307-318. doi:http://dx.doi.org/10.1111/j.1754-9434

Ullah, M., Kamran, H., Akram, S., Nawaz, M., \& Rehman, F. (2021). Organizational antecedents and talent turnover: A relational analysis of credit card departments of banks. Management Science Letters, 11(4), 1211-1220.

Usmani, S., Kumari, K., \& Siddiqui, S. J. (2016). Tenure as a Moderator Between Affective Commitment and Proactively. IBT Journal of Business Studies (JBS), 1(1). doi:https://doi.org/10.46745/ILMA.jbs.2016.121.03 